\title{
Vitamin D Status and Risk of Cystic Fibrosis-Related Diabetes: A Retrospective Single Center Cohort Study
}

\author{
Yiqing Peng ${ }^{1}$, Malinda $\mathrm{Wu}^{2}$, Jessica A. Alvarez ${ }^{3}$ and Vin Tangpricha ${ }^{3,4, *}$ \\ 1 Emory College, Emory University, Atlanta, GA 30322, USA; whitney.peng@emory.edu \\ 2 Division of Endocrinology, Department of Pediatrics, Emory University School of Medicine, \\ Atlanta, GA 30322, USA; malinda.wu@alumni.emory.edu \\ 3 Division of Endocrinology, Metabolism \& Lipids, Department of Medicine, Emory University School \\ of Medicine, Atlanta, GA 30322, USA; jessica.alvarez@emoryed.edu \\ 4 Atlanta VA Medical Center, Decatur, GA 30300, USA \\ * Correspondence: vin.tangpricha@emory.edu
}

Citation: Peng, Y.; Wu, M.; Alvarez, J.A.; Tangpricha, V. Vitamin D Status and Risk of Cystic Fibrosis-Related Diabetes: A Retrospective Single Center Cohort Study. Nutrients 2021, 13, 4048. https://doi.org/ 10.3390/nu13114048

Academic Editor: Genevieve Mailhot

Received: 22 September 2021

Accepted: 8 November 2021

Published: 12 November 2021

Publisher's Note: MDPI stays neutral with regard to jurisdictional claims in published maps and institutional affiliations.

Copyright: (c) 2021 by the authors. Licensee MDPI, Basel, Switzerland. This article is an open access article distributed under the terms and conditions of the Creative Commons Attribution (CC BY) license (https:// creativecommons.org/licenses/by/ $4.0 /)$.

\begin{abstract}
Objective: Cystic fibrosis-related diabetes (CFRD) affects up to half of the people with cystic fibrosis (CF) by adulthood. CFRD is primarily caused by pancreatic dysfunction that leads to insufficient insulin release and/or insulin resistance. Exocrine pancreatic insufficiency in people with CF is associated with fat-soluble vitamin malabsorption, including vitamins A, D, E, and K. This study examined the relationship between vitamin $\mathrm{D}$ status, assessed by serum 25-hydroxyvitamin $\mathrm{D}(25(\mathrm{OH}) \mathrm{D})$, and the development of CF-related diabetes (CFRD) in adults with CF. Methods: This was a retrospective cohort study of adults seen at a single CF center. The data were extracted from the electronic medical records and the Emory Clinical Data Warehouse, a data repository of health information from patients seen at Emory Healthcare. We collected age, race, the first recorded serum 25-hydroxyvitamin D (25(OH)D) concentration, body mass index (BMI), and onset of diabetes diagnosis. Log-rank (Mantel-Cox) tests were used to compare the relative risk of CFRD onset in the subjects with stratified vitamin D status and weight status. A sub-group analysis using chi-square tests assessed the independence between vitamin D deficiency and CFRD risk factors, including gender and CF mutation types (homozygous or heterozygous for F508del, or others). Unpaired $t$-tests were also used to compare the BMI values and serum 25(OH)D between the CF adults based on the CFRD development. Results: This study included 253 subjects with a mean age of 27.1 years $( \pm 9.0)$, a mean follow-up time period of $1917.1( \pm 1394.5)$ days, and a mean serum $25(\mathrm{OH}) \mathrm{D}$ concentration of $31.8 \mathrm{ng} / \mathrm{mL}( \pm 14.0)$. The majority $(52.6 \%)$ of the subjects developed CFRD during the study period. Vitamin D deficiency (defined as $25(\mathrm{OH}) \mathrm{D}<20 \mathrm{ng} / \mathrm{mL}$ ) was present in $25.3 \%$ of the subjects. Close to two thirds $(64.1 \%)$ of the subjects with vitamin D deficiency developed CFRD during the study. Vitamin D deficiency increased the risk of developing CFRD (chi-square, $p=0.03$ ) during the course of the study. The time to the onset of CFRD stratified by vitamin D status was also significant $(25(\mathrm{OH}) \mathrm{D}<20 \mathrm{ng} / \mathrm{mL}$ vs. $25(\mathrm{OH}) \mathrm{D} \geq 20 \mathrm{ng} / \mathrm{mL})(95 \% \mathrm{CI}: 1.2,2.7, p<0.0078)$. Conclusion: Our findings support the hypothesis that adults with $\mathrm{CF}$ and vitamin $\mathrm{D}$ deficiency are at a higher risk of developing CFRD and are at risk for earlier CFRD onset. The maintenance of a serum 25(OH)D concentration above $20 \mathrm{ng} / \mathrm{mL}$ may decrease the risk of progression to CFRD.
\end{abstract}

Keywords: cystic fibrosis; vitamin D; vitamin D deficiency; diabetes; epidemiology

\section{Introduction}

Cystic fibrosis (CF) is an autosomal recessive disorder caused by a mutation of the cystic fibrosis transmembrane conductance regulator (CFTR) gene. The complications of CF include chronic bacterial infection in the lungs, CF-related diabetes, pancreatic insufficiency, and a decline in lung function [1,2]. Exocrine pancreatic insufficiency leads to fat malabsorption and a deficiency in fat-soluble vitamins, including vitamin $A, D$, $\mathrm{E}$, and $\mathrm{K}$ [3]. Vitamin D deficiency can subsequently lead to CF bone disease and an 
increased risk of fractures [4,5]. Endocrine pancreatic insufficiency, along with other contributing risk factors, such as body weight, diet, and physical activity, can lead to CF-related diabetes (CFRD). Close to half of the adults with CF will develop CFRD, which is characterized by insufficient insulin production, reduced pancreatic beta cell activity, and insulin resistance [2].

It is well established that vitamin D plays important roles in maintaining bone health, calcium homeostasis in blood, and preventing osteoporosis [6]. Vitamin D insufficiency $(25(\mathrm{OH}) \mathrm{D}<30 \mathrm{ng} / \mathrm{mL})$, which is commonly observed in people with $\mathrm{CF}$, has been associated with decreased insulin sensitivity and secretion in both animal and human studies [7,8]. The best marker of vitamin D status is the total serum 25-hydroxyvitamin D (25(OH)D), which accounts for both the endogenous production of vitamin D from the skin and dietary intake of vitamin D-containing foods and supplements [9]. A serum 25(OH)D level of less than $30 \mathrm{ng} / \mathrm{mL}$ is considered as insufficient, whereas a $25(\mathrm{OH}) \mathrm{D}$ of less than $20 \mathrm{ng} / \mathrm{mL}$ is considered as vitamin D deficient $[10,11]$. A recent study suggested that vitamin D status is associated with glucose intolerance and CFRD [12], but it did not address whether vitamin D status influences the risk of CFRD development or time to CFRD onset. The mechanisms by which vitamin $\mathrm{D}$ protects against the development of diabetes are uncertain. However, pre-clinical studies have indicated that vitamin D may regulate insulin secretion and improve beta-cell function [13].

This current study focuses on the relationship between vitamin D deficiency and CFRD, two common endocrine co-morbidities found in CF. Given the association between vitamin $D$ status and the risk of CFRD, this study aimed to examine the impact of vitamin $D$ status on the onset of CFRD in adults with CF. We hypothesized that low vitamin D status is one of the risk factors for the development of CFRD in adults. The design of the study was a retrospective longitudinal cohort study of adults with CF receiving care at a single center. The data on the subject demographics, serum vitamin D $(25(\mathrm{OH}) \mathrm{D})$ measurements, and diabetes status were extracted from the medical records to examine the influence of vitamin D status on CFRD risk.

\section{Materials and Methods}

\subsection{Study Design}

This was a retrospective chart review examining the relationship between vitamin $\mathrm{D}$ status, assessed by serum 25-hydroxyvitamin D (25(OH)D), and development of CFRD. The research study was approved by the Emory Institutional Review Board (IRB). Subjects were adults, age greater than 18, with CF treated by the Emory CF Center and receiving care by the Emory Clinic and Emory Hospital from 2002-2012. Inclusion criteria included a confirmed diagnosis of $\mathrm{CF}$ and at least one serum 25(OH)D measurement taken between 1 January 2002 and 31 December 2012. Exclusion criteria included a diagnosis of CFRD at the time of first serum 25(OH)D measurement. Development of CFRD was defined as a diagnosis of CFRD in the medical record, initiation with diabetes medication, fasting glucose $\geq 126 \mathrm{mg} / \mathrm{dL}, 2 \mathrm{hr}$ oral glucose tolerance test (OGTT) glucose $\geq 200 \mathrm{mg} / \mathrm{dL}$, hemoglobin $\mathrm{A} 1 \mathrm{C}(\mathrm{HgbA} 1 \mathrm{c}) \geq 6.5 \%$, or classical symptoms of diabetes in the presence of a casual glucose $\geq 200 \mathrm{mg} / \mathrm{dL}$. Data from the electronic medical record or the CF Foundation Patient Registry (PortCF) were used to conduct the analysis. We collected data on each subject's serum 25(OH)D level, body mass index (BMI), date of diabetes diagnosis, presence of pancreatic insufficiency as defined as prescription of pancreatic enzymes, and the number of days since the start of study (1 January 2002) to diagnosis of CFRD, or, if not, to the end of study on 31 December 2012.

\subsection{Database and Categorization}

Data were obtained from the Emory Clinical Data Warehouse, an electronic database of all clinical laboratory data for the Emory Clinic, Emory University Hospital, and Emory CF Center. Data on pancreatic insufficiency by use of pancreatic enzymes and CFTR mutation were obtained from PortCF. The date of the onset of CFRD was determined by the first 
date recorded that the subject developed CFRD during the study period. Subjects who did not develop CFRD by the end of the study period were deemed not to have developed CFRD. The first serum $25(\mathrm{OH}) \mathrm{D}$ recorded in the electronic medical record during the study period was used to define a subject's vitamin D status. Vitamin D status deficiency was defined as a $25(\mathrm{OH}) \mathrm{D}<20 \mathrm{ng} / \mathrm{mL}$, and insufficient vitamin $\mathrm{D}$ level was defined as $25(\mathrm{OH}) \mathrm{D}<30 \mathrm{ng} / \mathrm{mL}$. Weight statuses were categorized based on subjects' BMI. A BMI of more than $25 \mathrm{~kg} / \mathrm{m}^{2}$ was considered as overweight, and BMI cut-offs greater than $22 \mathrm{~kg} / \mathrm{m}^{2}$ for female and $23 \mathrm{~kg} / \mathrm{m}^{2}$ for male subjects were considered as the recommended BMI level for adults with CF [14].

\subsection{Statistical Analysis}

Prism 9.0.1 was used to perform statistical analyses. The odds ratios between potential factors contributing to CFRD and vitamin D status were analyzed with $95 \%$ confidence interval. Freedom from CFRD was compared using log-rank (Mantel-Cox) tests, and all study subjects were free from CFRD at the beginning of the analysis. Log-rank tests compared the relative risk of CFRD onset in subjects with stratified vitamin D status and weight status. Sub-group analysis using chi-square tests assessed the independence between vitamin D deficiency and CFRD risk factors, including gender and CF mutation types (homozygous for F508del, heterozygous for F508del, or others). Unpaired $t$-test was also used to determine if BMI or first 25(OH)D measures differed between adults with CF who developed CFRD and those that did not.

\section{Results}

\subsection{Subject Demographics}

A total of 267 adults without CFRD were potentially eligible for the study. One patient was excluded due to an implausible BMI value of 43 , and 13 subjects were excluded due to missing BMI values. Eventually, 253 subjects met the inclusion criteria, and their baseline demographics are presented in Table 1, stratified by vitamin D deficiency status. During the course of the study, $52.6 \%$ of the subjects with CF developed CFRD. During the course of the study, $53.1 \%$ of the subjects with insufficient vitamin $\mathrm{D}(25(\mathrm{OH}) \mathrm{D}$ levels $<30 \mathrm{ng} / \mathrm{mL})$ developed CFRD. Using a cut-off value of $25(\mathrm{OH}) \mathrm{D}<20 \mathrm{ng} / \mathrm{mL}, 64.1 \%$ of vitamin D deficient subjects $(25(\mathrm{OH}) \mathrm{D}<20 \mathrm{ng} / \mathrm{mL})$ developed CFRD.

\subsection{Time to Onset of Cystic Fibrosis-Related Diabetes}

We examined the time to the onset of CFRD by vitamin D status (deficient or insufficient). The time to the onset of CFRD refers to the first instance that a subject had documentation of a CFRD diagnosis as defined in our methods. The log-rank (Mantel-Cox) test was used for the time of CFRD onset by insufficient vitamin D status $(25(\mathrm{OH}) \mathrm{D}<30 \mathrm{ng} / \mathrm{mL})$ and deficient vitamin $\mathrm{D}$ status $(25(\mathrm{OH}) \mathrm{D}<20 \mathrm{ng} / \mathrm{mL})$. No significant difference was observed in the time to the onset of CFRD in the subjects with CF compared to those with and without insufficient vitamin D status (hazard ratio: $0.84,95 \%$ CI: $0.60,1.18, p=0.31$ ). However, there was a statistically significant hazard ratio in the time to the onset of CFRD in the subjects with CF compared to those with $25(\mathrm{OH}) \mathrm{D}<20 \mathrm{ng} / \mathrm{mL}$ versus those with $25(\mathrm{OH}) \mathrm{D} \geq 20 \mathrm{ng} / \mathrm{mL}$ (Figure 1, hazard ratio: 1.76, 95\% CI: 1.2, 2.7, $p=0.0078$ ). Based on the survival curve in Figure 1,50\% of the subjects with a deficiency in vitamin D were diagnosed with CFRD at day 931, while, only after 3070 days, $50 \%$ of the subjects without deficient vitamin $\mathrm{D}$ were diagnosed with CFRD. 
Table 1. Baseline subject demographics stratified by vitamin D deficiency at $20 \mathrm{ng} / \mathrm{mL}$.

\begin{tabular}{|c|c|c|c|}
\hline & All Subjects & $\begin{array}{c}\text { Vitamin D Deficient } \\
(25(\mathrm{OH}) \mathrm{D} \\
<20 \mathrm{ng} / \mathrm{mL})\end{array}$ & $\begin{array}{c}\text { Vitamin D Not } \\
\text { Deficient } \\
(25(\mathrm{OH}) \mathrm{D} \\
\geq 20 \mathrm{ng} / \mathrm{mL})\end{array}$ \\
\hline Subjects n (\%) & 253 & $64(25.3)$ & $189(74.7)$ \\
\hline Age at Entry, y & $27.1( \pm 9.0)$ & $26.9( \pm 8.3)$ & $27.1( \pm 9.2)$ \\
\hline Gender, male & $132(52.2)$ & $39(60.1)$ & $93(49.2)$ \\
\hline Gender, female & $121(47.8)$ & $25(39.1)$ & $96(50.8)$ \\
\hline $\begin{array}{c}\text { Race, Caucasian or } \\
\text { White }^{\mathrm{a}}\end{array}$ & $231(91.3)$ & $47(73.4)$ & $186(97.4)$ \\
\hline $\begin{array}{c}\text { Race, African } \\
\text { American or Black }^{a}\end{array}$ & $18(7.1)$ & $16(25)$ & $2(1.1)$ \\
\hline $\begin{array}{c}\text { Days without } \\
\text { Diabetes Mellitus }\end{array}$ & $1917.1( \pm 1394.5)$ & $2161.2( \pm 1627.6)$ & $2410.7( \pm 1667.6)$ \\
\hline BMI, $\mathrm{kg} / \mathrm{m}^{2}$ & $21.8( \pm 3.4)$ & $21.8( \pm 3.8)$ & $21.7( \pm 3.3)$ \\
\hline BMI at goal ${ }^{c}$ & $165(65.2)$ & 45 (70.3) & $120(63.5)$ \\
\hline $\mathrm{BMI}^{\mathrm{d}},<25 \mathrm{~kg} / \mathrm{m}^{2}$ & $211(83.4)$ & $53(82.8)$ & $158(83.6)$ \\
\hline Developed CFRD $^{\text {e }}$ & $133(52.6)$ & $41(64.1)$ & $92(48.7)$ \\
\hline $25(\mathrm{OH}) \mathrm{D}, \mathrm{ng} / \mathrm{mL}$ & $31.8( \pm 14.0)$ & $12.5( \pm 4.4)$ & $36.9( \pm 15.5)$ \\
\hline
\end{tabular}

Entries are means ( \pm standard deviation), $\mathrm{n}(\%)$, or \% (n). ${ }^{\text {a }}$ Six missing values of race not reported. ${ }^{\mathrm{b}}$ Days, since study start on 1 January 2002. End date was the day when the subject was diagnosed with diabetes, or, if the subject never developed diabetes, 31 December 2012. ${ }^{\mathrm{c}}$ The BMI goal for adults with CF is greater than $22 \mathrm{~kg} / \mathrm{m}^{2}$ for females and $23 \mathrm{~kg} / \mathrm{m}^{2}$ for males. ${ }^{\mathrm{d}}$ BMI at or above $25 \mathrm{~kg} / \mathrm{m}^{2}$ is considered overweight. ${ }^{\text {e }}$ Developed diabetes between 2002-2012.

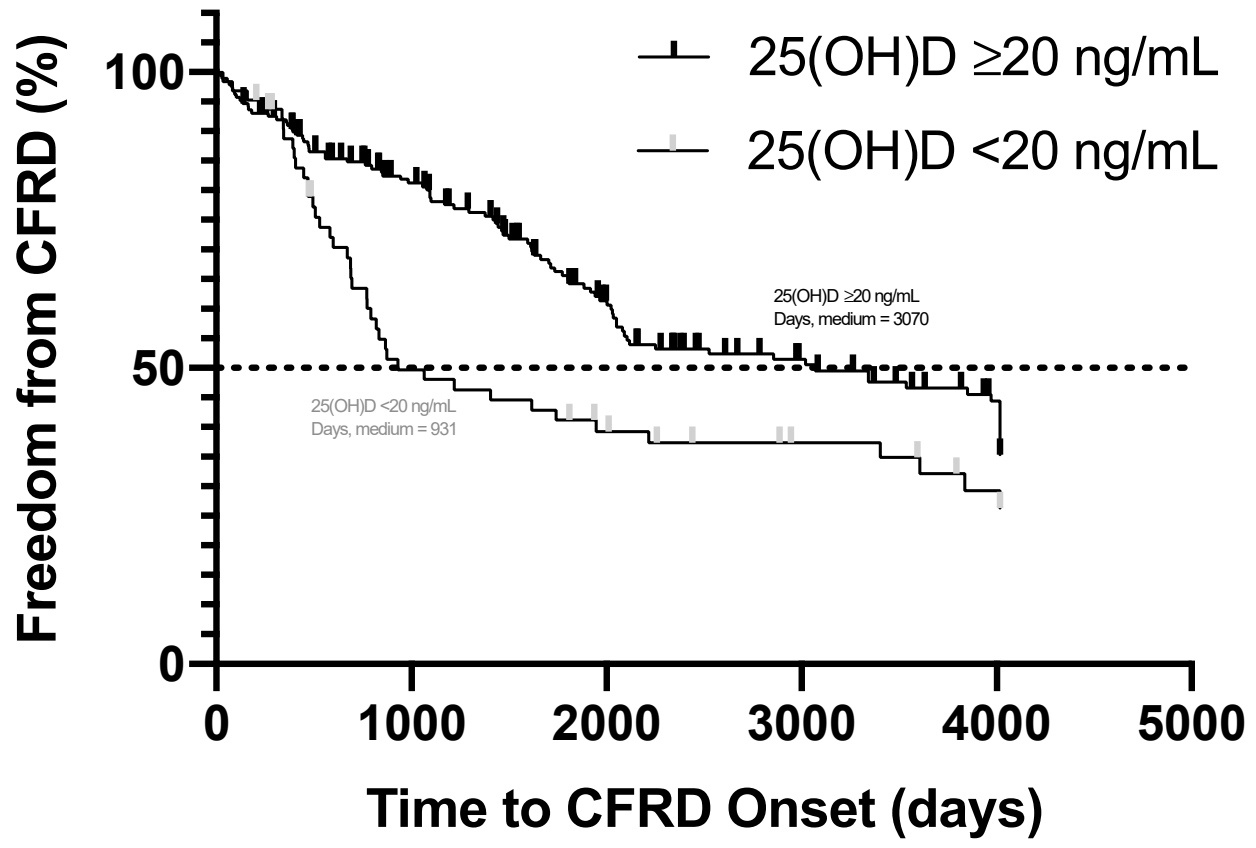

Figure 1. Time in days to cystic fibrosis-related diabetes (CFRD) onset by vitamin D status $(25(\mathrm{OH}) \mathrm{D}<$ and $\geq 20 \mathrm{ng} / \mathrm{mL}$ ). Hazard ratio of the vitamin D deficient subjects to not vitamin D deficient subjects is 1.76 (95\% CI: 1.2, 2.7, $p=0.0078$ ). The medium for days of CFRD onset was 931 for subjects with vitamin D deficiency and 3070 for those without. 


\subsection{Influence of Other Risk Factors, Including Vitamin D Status, on the Development of CFRD}

We evaluated other potential risk factors that may be associated with the development of CFRD. The sub-group analyses using chi-square tests assessed the independence between vitamin D deficiency and CFRD risk factors, including sex, CFTR mutation status (F508del homozygous, F508del heterozygous, or no F508del mutation), and pancreatic enzyme usage. Vitamin D deficiency $(25(\mathrm{OH}) \mathrm{D}<20 \mathrm{ng} / \mathrm{mL})$ was significantly associated with the development of CFRD (chi square, $p=0.03$ ) (Table 2). Insufficient vitamin D status $(25(\mathrm{OH}) \mathrm{D}<30 \mathrm{ng} / \mathrm{mL})$ was not associated with the risk of CFRD $(p=0.87)$ (Table 2). There were no significant associations between vitamin D deficiency and gender $(p=0.10)$, CF mutation type $(p=0.88)$, or pancreatic enzyme usage $(p=0.42)$. The unpaired $t$-test indicated that the first serum $25(\mathrm{OH}) \mathrm{D}$ measure at the start of the study $(p=0.83)$ and average BMI $(p=0.08)$ were not significantly different between the subjects who did and did not develop CFRD (Table 3).

Table 2. Sub-group analysis of vitamin D deficiency/insufficiency with selected demographic factors.

\begin{tabular}{|c|c|c|c|}
\hline & Compared Value & $\mathrm{X}^{2} . \mathrm{Df}$ & $p$-Value \\
\hline Vitamin D Deficiency $^{a}$ & CF Mutation Type ${ }^{b}$ & $0.27,2$ & 0.88 \\
\hline Vitamin D Deficiency & Develop CFRD & $4.54,1$ & $0.03 *$ \\
\hline Vitamin D Deficiency & Gender, Male or Female & $2.63,1$ & 0.10 \\
\hline Vitamin D Deficiency & Pancreatic Enzyme Usage $^{c}$ & $0.66,1$ & 0.42 \\
\hline Develop CFRD ${ }^{d}$ & Gender, Male or Female & $0.43,1$ & 0.51 \\
\hline Vitamin D Insufficiency ${ }^{\mathrm{e}}$ & Develop CFRD & $0.03,1$ & 0.87 \\
\hline
\end{tabular}

Results from sub-group analysis based on chi-square test analysis. ${ }^{a}$. Subjects stratified by vitamin D deficiency at $25(\mathrm{OH}) \mathrm{D}<20 \mathrm{ng} / \mathrm{mL}$. ${ }^{\text {b. }}$ CF mutation types categorized by F508del homozygous, F508del heterozygous, or no F508del mutation ${ }^{c}$. Pancreatic enzyme usage, yes or no, recorded at the start of study ${ }^{d}$. Subjects stratified by

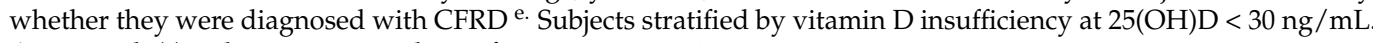
An asterisk $\left({ }^{*}\right)$ indicates statistical significance at $p<0.05$.

Table 3. Sub-group analysis of subjects developing CFRD during the course of the study.

\begin{tabular}{cccc}
\hline & Compared Value & t-Score, $\mathbf{d f}$ & $p$-Value \\
\hline Develop CFRD $^{\text {a }}$ & First $25(\mathrm{OH}) \mathrm{D}, \mathrm{ng} / \mathrm{mL}^{\mathrm{b}}$ & $0.22,251$ & 0.83 \\
\hline Develop CFRD & $\mathrm{BMI}, \mathrm{kg} / \mathrm{m}^{2}$ & $1.74,251$ & 0.08 \\
\hline Results from sub-group analysis based on unpaired $t$-test. ${ }^{\text {a }}$ Subjects stratified by whether they were diagnosed
\end{tabular}

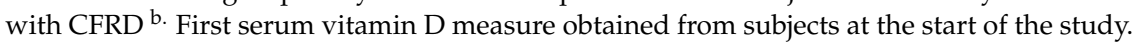

\section{Discussion}

This retrospective study aimed to investigate the relationship between vitamin $\mathrm{D}$ status, assessed by serum $25(\mathrm{OH}) \mathrm{D}$, and the development of CF-related diabetes (CFRD) in a cohort of subjects without CFRD followed over a 10-year period. As expected, we found that more than half of the subjects (52.6\%) developed CFRD over the course of the study, which is consistent with previous reports indicating the prevalence of CFRD in the CF population [2]. The results of our statistical analysis demonstrate that subjects with $\mathrm{CF}$ had a higher risk of CFRD development, with earlier onset in those with a deficient serum $25(\mathrm{OH}) \mathrm{D}$ level at less than $20 \mathrm{ng} / \mathrm{mL}$ compared to those with a serum $25(\mathrm{OH}) \mathrm{D}$ greater than $20 \mathrm{ng} / \mathrm{mL}$. Our sub-group analysis also indicated that, aside from the susceptibility to CFRD onset, the subjects with and without vitamin D deficiency were not significantly different in other CFRD-related markers, which included gender, BMI, first vitamin D measure, $\mathrm{CF}$ mutation types, and pancreatic enzyme usage.

Our findings support the findings that $25(\mathrm{OH}) \mathrm{D}>20 \mathrm{ng} / \mathrm{mL}$ may be protective against the development of CFRD. Pincikova et al. found that a serum 25(OH)D less than $20 \mathrm{ng} / \mathrm{mL}$ was associated with higher hemoglobin $\mathrm{A} 1 \mathrm{c}(\mathrm{HbA} 1 \mathrm{c})$ in a cross-sectional cohort composed of about 900 children and adults with CF living in Scandinavia, suggesting a relationship 
between vitamin $\mathrm{D}$ status and glucose concentrations [12]. The investigators found the association between vitamin $\mathrm{D}$ status and $\mathrm{HbA1} \mathrm{c}$ in children, but such an association was not as strong in adults with CF [12]. In contrast, a similar study performed by Coriati et al. found no relationship between the serum $25(\mathrm{OH}) \mathrm{D}$ and measures of glucose status performed by an oral glucose tolerance test in 270 adults with CF in Canada [15].

Studies examining vitamin $\mathrm{D}$ status and the risk of diabetes are also mixed in populations without CF. A systematic review by Mitri et al. found that, in eight observational studies, a greater than 500 IU of vitamin D intake per day was associated with a $13 \%$ decreased risk of type II diabetes compared to a vitamin D intake of less than $200 \mathrm{IU}$ per day [16]. However, there were no associations found in the development of type II diabetes in the post hoc analyses of randomized controlled trials [16]. A meta-analysis of vitamin $\mathrm{D}$ and the risk of type I diabetes found, in four case control studies, that vitamin D supplementation in early childhood reduced the risk of type I diabetes compared to children not supplemented with vitamin D [17]. A recent large multi-center randomized controlled trial found that vitamin D supplementation did not protect against the progression from prediabetes to type II diabetes in adults [18]. Therefore, the current literature is mixed in regard to the potential effect of vitamin $\mathrm{D}$ on the development of diabetes, with some potential protection of vitamin $\mathrm{D}$ in children with type I diabetes but no benefits seen in adults with type II diabetes and prediabetes.

Vitamin D is thought to be protective against the development of type I diabetes by modulating the immune system by dampening the autoimmune response, decreasing selfdestructive islet cell auto-antibodies produced by beta-cells, and, thus, preserving the betacell mass of the pancreas. In murine models of type I diabetes mellitus, supplementation with the active form of vitamin D, calcitriol, prevented the onset of diabetes, which further supported the role of vitamin $\mathrm{D}$ in the prevention of type I diabetes $[19,20]$. For type II diabetes, vitamin $\mathrm{D}$ was thought to enhance insulin sensitivity; however, a recent metaanalysis of 18 randomized controlled trials found no benefit of vitamin D supplementation on the markers of insulin sensitivity [21]. Finally, a recent meta-analysis of vitamin D on the markers of inflammation and oxidative stress in people with diabetes found that vitamin $\mathrm{D}$ reduced C-reactive protein and malondialdehyde levels, both markers of inflammation. The supplementation of vitamin $\mathrm{D}$ also increased the nitric oxide release, serum antioxidant capacity, and total glutathione concentrations, favorable changes in oxidative stress [22]. Since CFRD shares some features of type I and II DM, vitamin D may have many roles in the prevention of diabetes by reducing inflammation, oxidative stress, and, potentially, by preserving beta-cell mass.

Optimal vitamin $\mathrm{D}$ status has been associated with the decreased risk of diabetes and prediabetes in populations without CF [23]. In addition, better vitamin D status among patients with diabetes and prediabetes is associated with a reduced risk for all-cause mortality $[24,25]$. However, in a randomized controlled trial of subjects with prediabetes and without $\mathrm{CF}$, intervention with $4000 \mathrm{IU}$ of vitamin $\mathrm{D}$ for 2.5 years did not reduce the progression to diabetes compared to a placebo [18]. Despite the protective mechanisms of vitamin $\mathrm{D}$, as outlined above, and the strong association between vitamin $\mathrm{D}$ status and the risk of diabetes, clinical trials have been negative in establishing a role of vitamin $\mathrm{D}$ supplementation for prevention of progression to diabetes. Thus, vitamin $\mathrm{D}$ intervention may need to be provided much earlier in life before beta cell dysfunction and/or vitamin D deficiency represents poor general health that is not modifiable by supplementation with vitamin D.

Our study found that a serum $25(\mathrm{OH}) \mathrm{D}>20 \mathrm{ng} / \mathrm{mL}$ was protective against the risk of CFRD. However, larger studies in the general population using the NHANES data have suggested that a cut-off of $30 \mathrm{ng} / \mathrm{mL}$ was protective against diabetes and metabolic syndrome [26]. The CF Foundation recommends a 25(OH)D level of greater than $30 \mathrm{ng} / \mathrm{mL}$ to protect against CF bone disease [27]. The $25(\mathrm{OH}) \mathrm{D}$ cut-off of $30 \mathrm{ng} / \mathrm{mL}$ to establish vitamin $\mathrm{D}$ sufficiency is based on recommendations in people without $\mathrm{CF}$, including a study showing no osteomalacia found on bone biopsy in adults with $25(\mathrm{OH}) \mathrm{D}$ concentrations 
greater than $30 \mathrm{ng} / \mathrm{mL}$ [28]. Some investigators have proposed even higher concentrations of 25(OH)D to prevent elevations in PTH concentrations to prevent bone loss [29]. While there is a general consensus that a $25(\mathrm{OH}) \mathrm{D}$ concentration of above $30 \mathrm{ng} / \mathrm{mL}$ is optimal for bone health in $\mathrm{CF}$, it is not known if different thresholds are protective against conditions such as CFRD, pulmonary exacerbations, or infections. Furthermore, different organ systems may need different thresholds for optimal health. Finally, the duration that $25(\mathrm{OH}) \mathrm{D}$ concentrations need to be sufficient is not known either. Studies indicate that the short-term correction of vitamin D status in CF, such as at the time of pulmonary exacerbation, does not change the course of the disease [30]. Until data are available to determine the optimal $25(\mathrm{OH}) \mathrm{D}$ concentration for all the health conditions in $\mathrm{CF}$, clinicians should still address vitamin $D$ status by supplementation or encouraging outdoor sunlight exposure in people with CF [9,31].

This is the first study that analyzed the long-term impact of vitamin D status on the onset of diabetes specifically in adults with CF. Limitations to our study include the limited reports on the use of any pancreatic enzymes, the interaction of vitamin $\mathrm{D}$ and CFTR modulator therapy, and the types of CFTR mutations in the entire subject population. Another limitation is the lack of data on other potential risk factors for the development of CFRD. Since this was a retrospective study, we lacked information on diet, physical activity, medications, and other health conditions. Only 68 of the 253 subjects had records of CFTR mutation and whether they were prescribed with pancreatic enzymes during their treatment regimes. Although CF mutation types and pancreatic enzyme usage were used as indicators for pancreatic insufficiency, we were unable to draw substantial conclusion due to the sample size of less than 20 when stratified based on vitamin D status. Understanding the CFTR mutation type and the usage of pancreatic enzyme is important to adjust for equal sampling distribution because both factors can potentially affect vitamin D deficiency and diabetes onset. Having an F508 del homozygous mutation is associated with more severe CF complications and a higher risk of pancreatic defects [1]. Therefore, adults with an F508del homozygous mutation might have a higher risk of diabetes development despite the vitamin D status.

Our findings support the hypothesis that adults with CF and vitamin D deficiency are at a higher risk of developing CFRD and are at risk for earlier CFRD onset. We found that a serum $25(\mathrm{OH}) \mathrm{D}$ concentration above $20 \mathrm{ng} / \mathrm{mL}$ may decrease the risk of the progression to CFRD. However, what is not clear and cannot be answered in this retrospective study is whether providing vitamin D supplements will actually decrease the progression to CFRD. Future randomized prospective studies should evaluate whether vitamin D supplementation with vitamin $\mathrm{D}$ in adults and/or children can decrease the progression to CFRD.

Author Contributions: V.T., J.A.A., Y.P. were responsible for the conceptualization, design, and methodology of the study, data collection, formal analysis and interpretation of the data. V.T. and J.A.A. were responsible for the resources, project administration and supervision. V.T., J.A.A., Y.P., M.W. were responsible for the writing-original draft, writing-review and editing. All authors have read and agreed to the published version of the manuscript.

Funding: Supported by the National Institutes of Health (NIH) Center for Advancing Translational Sciences under Award Number UL1TR002378, National Institute of Diabetes and Digestive and Kidney Diseases under awards numbers P30DK125013 and R03DK117246, and the Cystic Fibrosis Foundation (V.T., M.W., J.A.A.).

Institutional Review Board Statement: The study was approved by Emory University IRB Study \#IRB00002092.

Informed Consent Statement: Patient consent was waived due to the study design of a retrospective chart review.

Conflicts of Interest: The authors report no financial conflict of interest. The funders had no role in the design of the study; in the collection, analyses, or interpretation of data; in the writing of the manuscript, or in the decision to publish the results. 


\section{References}

1. Strausbaugh, S.D.; Davis, P.B. Cystic fibrosis: A review of epidemiology and pathobiology. Clin. Chest Med. 2007, 28, 279-288. [CrossRef]

2. Alvarez, J.A.; Ashraf, A. Role of vitamin d in insulin secretion and insulin sensitivity for glucose homeostasis. Int. J. Endocrinol. 2010, 2010, 351385. [CrossRef] [PubMed]

3. Bertolaso, C.; Groleau, V.; Schall, J.I.; Maqbool, A.; Mascarenhas, M.; Latham, N.E.; Dougherty, K.A.; Stallings, V.A. Fat-soluble vitamins in cystic fibrosis and pancreatic insufficiency: Efficacy of a nutrition intervention. J. Pediatr. Gastroenterol. Nutr. 2014, 58, 443-448. [CrossRef]

4. Donovan, D.S., Jr.; Papadopoulos, A.; Staron, R.B.; Addesso, V.; Schulman, L.; McGREGOR, C.; Cosman, F.; Lindsay, R.L.; Shane, E. Bone mass and vitamin D deficiency in adults with advanced cystic fibrosis lung disease. Am. J. Respir. Crit. Care Med. 1998, 157, 1892-1899. [CrossRef] [PubMed]

5. $\quad$ Aris, R.M.; Renner, J.B.; Winders, A.D.; Buell, H.E.; Riggs, D.B.; Lester, G.E.; Ontjes, D.A. Increased rate of fractures and severe kyphosis: Sequelae of living into adulthood with cystic fibrosis. Ann. Intern. Med. 1998, 128, 186-193. [CrossRef]

6. Khazai, N.; Judd, S.E.; Tangpricha, V. Calcium and vitamin D: Skeletal and extraskeletal health. Curr. Rheumatol. Rep. 2008, 10, 110-117. [CrossRef]

7. Palomer, X.; González-Clemente, J.M.; Blanco-Vaca, F.; Mauricio, D. Role of vitamin D in the pathogenesis of type 2 diabetes mellitus. Diabetes Obes. Metab. 2008, 10, 185-197. [CrossRef]

8. Pittas, A.G.; Lau, J.; Hu, F.B.; Dawson-Hughes, B. The role of vitamin D and calcium in type 2 diabetes. A systematic review and meta-analysis. J. Clin. Endocrinol. Metab. 2007, 92, 2017-2029. [CrossRef] [PubMed]

9. Tangpricha, V.; Kelly, A.; Stephenson, A.; Maguiness, K.; Enders, J.; Robinson, K.A.; Marshall, B.C.; Borowitz, D.; Cystic Fibrosis Foundation Vitamin D Evidence-Based Review Committee. An update on the screening, diagnosis, management, and treatment of vitamin D deficiency in individuals with cystic fibrosis: Evidence-based recommendations from the Cystic Fibrosis Foundation. J. Clin. Endocrinol. Metab. 2012, 97, 1082-1093. [CrossRef]

10. Holick, M.F. Vitamin D deficiency. N. Engl. J. Med. 2007, 357, 266-281. [CrossRef] [PubMed]

11. Holick, M.F.; Binkley, N.C.; Bischoff-Ferrari, H.A.; Gordon, C.M.; Hanley, D.A.; Heaney, R.P.; Murad, M.H.; Weaver, C.M. Evaluation, treatment, and prevention of vitamin D deficiency: An Endocrine Society clinical practice guideline. J. Clin. Endocrinol. Metab. 2011, 96, 1911-1930. [CrossRef]

12. Pincikova, T.; Nilsson, K.; Moen, I.E.; Fluge, G.; Hollsing, A.; Knudsen, P.K.; Lindblad, A.; Mared, L.; Pressler, T.; Hjelte, L. Vitamin D deficiency as a risk factor for cystic fibrosis-related diabetes in the Scandinavian Cystic Fibrosis Nutritional Study. Diabetologia 2011, 54, 3007-3015. [CrossRef]

13. Daley, T.; Hughan, K.; Rayas, M.; Kelly, A.; Tangpricha, V. Vitamin D deficiency and its treatment in cystic fibrosis. J. Cyst. Fibros. 2019, 18 (Suppl. 2), S66-S73. [CrossRef]

14. Stallings, V.A.; Stark, L.J.; Robinson, K.A.; Feranchak, A.P.; Quinton, H.; Clinical Practice Guidelines on Growth and Nutrition Subcommittee; Ad Hoc Working Group. Evidence-based practice recommendations for nutrition-related management of children and adults with cystic fibrosis and pancreatic insufficiency: Results of a systematic review. J. Am. Diet. Assoc. 2008, 108, 832-839. [CrossRef] [PubMed]

15. Coriati, A.; Dubois, C.L.; Phaneuf, M.; Mailhot, M.; Lavoie, A.; Berthiaume, Y.; Rabasa-Lhoret, R. Relationship between vitamin D levels and glucose tolerance in an adult population with cystic fibrosis. Diabetes Metab. 2016, 42, 135-138. [CrossRef] [PubMed]

16. Mitri, J.; Muraru, M.D.; Pittas, A.G. Vitamin D and type 2 diabetes: A systematic review. Eur. J. Clin. Nutr. 2011, 65, 1005-1015. [CrossRef]

17. Zipitis, C.S.; Akobeng, A.K. Vitamin D supplementation in early childhood and risk of type 1 diabetes: A systematic review and meta-analysis. Arch. Dis. Child. 2008, 93, 512-517. [CrossRef] [PubMed]

18. Pittas, A.G.; Dawson-Hughes, B.; Sheehan, P.; Ware, J.H.; Knowler, W.C.; Aroda, V.R.; Brodsky, I.; Ceglia, L.; Chadha, C.; Chatterjee, R.; et al. Vitamin D supplementation and prevention of type 2 diabetes. N. Engl. J. Med. 2019, 381, 520-530. [CrossRef]

19. Cristelo, C.; Machado, A.; Sarmento, B.; Gama, F.M. The roles of vitamin D and cathelicidin in type 1 diabetes susceptibility. Endocr. Connect. 2021, 10, R1-R12. [CrossRef]

20. Zella, J.B.; McCary, L.C.; DeLuca, H.F. Oral administration of 1, 25-dihydroxyvitamin D3 completely protects NOD mice from insulin-dependent diabetes mellitus. Arch. Biochem. Biophys. 2003, 417, 77-80. [CrossRef]

21. Pramono, A.; Jocken, J.W.E.; Blaak, E.E.; van Baak, M.A. The Effect of Vitamin D Supplementation on Insulin Sensitivity: A Systematic Review and Meta-analysis. Diabetes Care 2020, 43, 1659-1669. [CrossRef] [PubMed]

22. Mansournia, M.A.; Ostadmohammadi, V.; Lankarani, K.B.; Tabrizi, R.; Kolahdooz, F.; Heydari, S.T.; Kavari, S.H.; Mirhosseini, M.; Mafi, A.; Dastorani, M. The effects of vitamin D supplementation on biomarkers of inflammation and oxidative stress in diabetic patients: A systematic review and meta-analysis of randomized controlled trials. Horm. Metab. Res. 2018, 50, 429-440. [CrossRef] [PubMed]

23. Martins, D.; Wolf, M.; Pan, D.; Zadshir, A.; Tareen, N.; Thadhani, R.; Felsenfeld, A.; Levine, B.; Mehrotra, R.; Norris, K. Prevalence of cardiovascular risk factors and the serum levels of 25-hydroxyvitamin D in the United States: Data from the Third National Health and Nutrition Examination Survey. Arch. Intern. Med. 2007, 167, 1159-1165. [CrossRef] [PubMed]

24. Wan, Z.; Guo, J.; Pan, A.; Chen, C.; Liu, L.; Liu, G. Association of Serum 25-Hydroxyvitamin D Concentrations with All-Cause and Cause-Specific Mortality among Individuals with Diabetes. Diabetes Care 2021, 44, 350-357. [CrossRef] [PubMed] 
25. Lu, Q.; Wan, Z.; Guo, J.; Liu, L.; Pan, A.; Liu, G. Association between Serum 25-hydroxyvitamin D Concentrations and Mortality among Adults with Prediabetes. J. Clin. Endocrinol. Metab. 2021, 106, e4039-e4048. [CrossRef] [PubMed]

26. Ganji, V.; Tangpricha, V.; Zhang, X. Serum Vitamin D Concentration $\geq 75 \mathrm{nmol} / \mathrm{L}$ Is Related to Decreased Cardiometabolic and Inflammatory Biomarkers, Metabolic Syndrome, and Diabetes; and Increased Cardiorespiratory Fitness in US Adults. Nutrients 2020, 12, 730. [CrossRef]

27. Chesdachai, S.; Tangpricha, V. Treatment of vitamin D deficiency in cystic fibrosis. J. Steroid Biochem. Mol. Biol. 2016, 164, 36-39. [CrossRef] [PubMed]

28. Priemel, M.; von Domarus, C.; Klatte, T.O.; Kessler, S.; Schlie, J.; Meier, S.; Proksch, N.; Pastor, F.; Netter, C.; Streichert, T.; et al. Bone mineralization defects and vitamin D deficiency: Histomorphometric analysis of iliac crest bone biopsies and circulating 25-hydroxyvitamin D in 675 patients. J. Bone Miner. Res. 2010, 25, 305-312. [CrossRef]

29. West, N.E.; Lechtzin, N.; Merlo, C.A.; Turowski, J.B.; Davis, M.E.; Ramsay, M.Z.; Watts, S.L.; Stenner, S.P.; Boyle, M.P. Appropriate goal level for 25-hydroxyvitamin D in cystic fibrosis. Chest 2011, 140, 469-474. [CrossRef] [PubMed]

30. Tangpricha, V.; Lukemire, J.; Chen, Y.; Binongo, J.N.G.; Judd, S.E.; Michalski, E.S.; Lee, M.J.; Walker, S.; Ziegler, T.R.; Tirouvanziam, R.; et al. Vitamin D for the Immune System in Cystic Fibrosis (DISC): A double-blind, multicenter, randomized, placebo-controlled clinical trial. Am. J. Clin. Nutr. 2019, 109, 544-553. [CrossRef]

31. Bhimavarapu, A.; Deng, Q.; Bean, M.; Lee, N.; Ziegler, T.R.; Alvarez, J.; Tangpricha, V. Factors Contributing to Vitamin D Status at Hospital Admission for Pulmonary Exacerbation in Adults with Cystic Fibrosis. Am. J. Med. Sci. 2021, 361, 75-82. [CrossRef] [PubMed] 